\title{
Koruyucu Madde Paraben'in Allium cepa L.'daki Fizyolojik, Anatomik ve Sitogenetik Etkilerinin Araştırılması
}

\author{
Deniz KURT ${ }^{1}$, Kültiğin ÇAVUŞOĞLU² ${ }^{2}$, Emine YALÇIN²
}

ÖZET: Bu çalışmada, günlük yaşamımızda sıkça kullandığımız kozmetik ve temizlik ürünleri başta olmak üzere, pek çok ürünün bileşiminde yer alan Metil Paraben'in Allium cepa $\mathrm{L}$. test materyalinde teşvik ettiği toksisite fizyolojik, sitogenetik ve anatomik parametreler kullanılarak araştırılmıştır. Fizyolojik parametreler; çimlenme yüzdesi, kök uzunluğu ve ağılık artı̧̧ının ölçülmesiyle, sitogenetik parametreler; mikronukleus sıklığı, kromozomal anormallikler ve mitotik indeks değerlerinin tespitiyle, anatomik parametreler ise kök uçlarından alınan kesitlerin mikroskopta incelenmesiyle araştırılmıştır. A. cepa L. tohumları bir (1) kontrol ve üç (3) uygulama olmak üzere toplam dört (4) gruba ayrılmış, 72 saat süresince, kontrol grubundaki tohumlar çeşme suyu, uygulama grubundaki tohumlar ise Metil Parabenin 100, 250 ve 500 mM dozları ile muamele edilmişlerdir. Süre sonunda kök uçları rutin preparasyon işlemlerine tabi tutulmuş, boyanmış ve mikroskobik incelemeler için hazır hale getirilmiştir. Sonuçta, paraben uygulamasının doza bağlı olarak çimlenme yüzdesi, kök uzunluğu, ağırlık artıșı ve mitotik indeks değerlerinde istatistiksel olarak önemli $(p<0.05)$ bir azalmaya, mikronukleus ve kromozomal anormallik sayılarında ise önemli $(\mathrm{p}<0.05)$ bir artışa neden olduğu gözlenmiştir. Ayrıca, paraben uygulaması kök ucu hücrelerinde yassılaşmış hücre çekirdeği, nekroz, korteks hücre çeperlerinde kalınlaşma, belirgin olmayan iletim doku, hücre deformasyonu ve korteks hücrelerinde bazı maddelerin birikimi şeklinde anatomik değişimlere neden olmuştur. Sonuç olarak, paraben'in belirli bir doz seviyesinde toksik etki gösterdiği, A. cepa L. test materyalinin ise söz konusu etkinin belirlenmesinde oldukça kullanışlı bir biyolojik indikatör olduğu gösterilmiştir.

Anahtar Kelimeler: Allium cepa L., anatomi, fizyoloji, genotoksisite, metil paraben

\section{The Investigation of Physiological, Anatomical and Cytogenetic Effects of Protective Substance Paraben in Allium cepa $\mathbf{L}$.}

\begin{abstract}
In this study, toxicity induced by Allium cepa L. test material of Methyl Paraben which is included in many products, especially cosmetic and cleaning products which we use frequently in our daily life, was investigated by using physiological, cytogenetic and anatomical parameters. Physiological parameters; germination percentage, root length and weight gain, cytogenetic parameters; by determining the micronucleus frequency, chromosomal abnormalities and mitotic index, anatomical parameters were investigated by microscopic examination of the sections taken from the root tips. A. cepa L. seeds were divided into four (4) groups, one (1) control and three (3) applications, for 72 hours, the seeds in the control group were treated with tap water and the seeds in the treatment group were treated with doses of 100, 250 and $500 \mathrm{mM}$ of Methyl Paraben. At the end of the period, root tips were subjected to routine preparations, stained and made ready for microscopic examinations. Eventually, there was a statistically significant decrease $(\mathrm{p}<0.05)$ in the germination percentage, root length, weight gain and mitotic index values of the Paraben application, although there was a statistically significant an increase $(p<0.05)$ in the micronucleus and chromosomal abnormality numbers. In addition, Paraben administration has resulted in anatomical changes in the root cells of the flattened cell nucleus, necrosis, thickening of the cell walls of the cortex, nonspecific vascular tissue, cell deformation, and accumulation of certain substances in the cortex cells. As a result, it has been shown that Paraben shows toxic effect at a certain dose level and $A$. cepa L. test material is a useful biological indicator in determining its effect.
\end{abstract}

Keywords: Allium cepa L., anatomy, genotoxicity, methyl paraben, physiology

Deniz KURT (0000-0001-5901-398X), Giresun Üniversitesi, Fen Bilimleri Enstitüsü, Biyoloji, Giresun, Türkiye

Kültiğin ÇAVUŞOĞLU (0000-0002-4767-9132), Emine YALÇIN (0000-0002-5280-5375), Giresun Üniversitesi, Fen Edebiyat Fakültesi, Biyoloji, Giresun, Türkiye

Sorumlu yazar/Corresponding Author: Kültiğin ÇAVUŞOĞLU, kultigincavusoglu@mynet.com

Bu çalışma 23-27 Haziran 2014 tarihinde Eskişehir-Türkiye'de düzenlenen 22. Ulusal Biyoloji Kongresi’nde sunulmuş ve kongre özet kitabında yayınlanmıştır. 


\section{GİRiș}

Doğada kendi halinde bulunabildiği gibi sentetik yollarla da üretilebilen yâda herhangi bir işlem sırasında atık olarak ortaya çıkabilen veya kazara oluşabilen element, bileşik ve karışım olarak bulunabilen maddelere kimyasal madde denir (Yücel, 2006). Kimyasal maddelerin hayatın her alanında kullanımı son yıllarda çok hızlı bir şekilde artmış, bu artış beraberinde, güvenlik sorunları ve maruziyetten kaynaklanan sağlık riskleri ile ilgili endişeleri de beraberinde getirmiştir. Yaşamı kolaylaştırmak için üretilen kimyasal maddeler, doğru ve dikkatli kullanılmadıklarında; toprak verimliliğinin azalmasına, çevre kirliliğine, üreme bozuklukları ve genetik hastalıklar ile ölüme neden olabilmektedirler. Herhangi bir kimyasalın canlı organizma üzerindeki toksik etkisi; kimyasalın dozu ve organizmada biriken konsantrasyonuna bağlı olarak değişmektedir (Slobodkin, 1967). Bugün soluduğumuz havadan, günlük olarak kullandığımız temizlik ve makyaj malzemelerinden, cilt bakım ürünlerine kadar kimyasallar yaşamımızın her alanına girmiş durumdadır. Günlük yaşamımızda sıkça maruz kaldığımız kimyasallardan biride parabendir.

Para-hidroksibenzoik asidin esterleri olan parabenin, metilparaben, etilparaben, propilparaben ve butilparaben şeklinde farklı formları bulunmaktadır (Andersen, 2008). Parabenler; kişisel bakım, kozmetik, ilaç ve gıda ürünlerinin yapısında kullanılan koruyucu maddelerdir. Paraben içeren başlıca ürünler; el sabunları, vücut losyonları, saç kremleri, yüz losyonları, şampuanlar, yüz temizleyicileri, rujlar, maskara, saç spreyleri, duş jelleri, diş macunları ve güneş kremleri vb. şeklinde siralanabilir (Johnsson et al., 2011; Witorsch and Thomas, 2010). Ayrıca birçok bilimsel çalışma atık su, nehir, toprak ve ev tozlarında dahi parabenlerin varlığını göstermiştir. Parabenler insan dokuları ve anne sütü, idrar ve seminal sıvı gibi vücut sıvılarında da tespit edilmiş, özellikle Meme Kanseri hastalarının meme dokularında bu kimyasal bileşiklerin keşfi, kullanımları konusunda kamuoyunu oldukça endişelendirmiştir. Özellikle koltuk altı deodorantından kaynaklanan paraben maruziyetinin, Meme Kanseri gelişim insidansını arttırdığı ve ayrıca parabenlerin östrojenik özelliklerinin de Gögüs Kanseri gelişiminde rol oynadığg düşünülmektedir (Johnsson et al., 2011; Kirchhof and De Gannes, 2013).

Song et al., (1989) tarafından gerçekleştirilen in vitro bir çalışmada, $1 \mathrm{mg} \mathrm{mL}^{-1}$ konsantrasyonunda parabene maruz bırakılan insan sperminin canlılığını yitirdiği tespit edilmiştir. Kang et al., (2002) tarafından gerçekleştirilen benzer bir çalışmada ise paraben maruziyetinin ratlarda sperm sayıs1 ve aktivitesinde azalmaya neden olduğu rapor edilmiştir. Bu çalışmada günlük yaşamda sıkça kullanılan pek çok ürünün yapisinda bulunan paraben'in muhtemel toksik etkileri fizyolojik, sitogenetik ve anatomik parametreler kullanılarak A. cepa L. test materyali ile araştırılmıştır.

\section{MATERYAL VE YÖNTEM}

\section{Kök Uçlarının Hazırlanması}

$\mathrm{Bu}$ çalışmada, metil paraben'in (Sigma Aldrich CAS Number 99-76-3) 100, 250 ve 500 mM'lik dozları kullanılmıştır. Araştırma materyali olarak ortalama aynı büyüklükteki $A$. серa $\mathrm{L}$. tohumları seçilmiştir. Tohumlar bir (1) kontrol ve üç (3) uygulama olarak toplam dört (4) gruba ayrılmıştır. Kontrol grubundaki tohumlar çeşme suyu, uygulama grubundaki tohumlar ise sirasiyla metil paraben'in 100,250 ve $500 \mathrm{mM}^{\prime} \mathrm{l}_{\mathrm{k}}$ dozlarıyla muamele edilmiştir. Tohumlar $85 \times 100 \mathrm{~cm}$ çapında plastik beherlere yerleştirilmiş, $25^{\circ} \mathrm{C}$ 'de 72 saat süresince çimlendirilmiş ve çimlenme süresince kurumamaları için gerekli solüsyon ilaveleri yapılmıştır. Süre sonunda kök uçları distile su ile yıkanmış ve geleneksel ezme preparasyon işlemleri uygulanarak, sitogenetik analizler için hazır hale getirilmiştir (Wei, 2004).

\section{Kök Uzunluğu, Ağırlık Artışı ve Çimlenme Yüzdesinin Tespiti}

Çimlenen tohumların kök uzunlukları radikula oluşumu temel alınarak milimetrik cetvel yardımıyla, ağırlık artışları ise hassas terazi yardımıyla ölçülmüştür. Ağırlık artışları uygulama öncesi ve sonrası tohum ağırlık farklarının hesaplanmasıyla tespit edilmiştir. Çimlenme yüzdesi ise "Eşitlik 1" kullanılarak belirlenmiştir (Atik ve ark., 2007).

$$
\text { Çimlenme Yüzdesi }(\%)=\frac{\text { Çimlenen tohum sayısı }}{\text { Toplam tohum sayısı }} \times 100
$$




\section{Kromozomal Anormallik, Mitotik İndeks ve Mikronukleus Testi}

Kromozomal anormalliklerin tespiti için kök uçları yaklaşık 1-2 cm uzunluğunda kesilerek, 2 saat süresince "Clarke" fiksatöründe (3:etanol / 1:glasial asetik asit) bekletilmiş, $15 \mathrm{dk} \% 96^{\prime} \mathrm{l}$ k etanol $\left(\mathrm{C}_{2} \mathrm{H}_{6} \mathrm{O}\right)^{\prime} \mathrm{de}$ yıkanmış ve $+4{ }^{\circ} \mathrm{C}$ ' de $\% 70$ 'lik etanolde bekletilmiştir. Daimi preparasyon için kök uçları $60{ }^{\circ} \mathrm{C}$ 'de $17 \mathrm{dk}$ $1 \mathrm{~N}$ HCI'de hidrolize edilmiş ve $30 \mathrm{dk} \% 45$ 'lik asetik asitte $\left(\mathrm{CH}_{3} \mathrm{COOH}\right)$ bekletilmiştir. Son aşamada ise, kök uçları 24 saat Aseto Karmin ile boyanmış, \%45'lik asetik asitte ezilmiş ve mikroskopta X500 büyütmede fotoğraflandırılmıştır (Staykova et al., 2005).
Mikronukleus (MN) sıklı̆̆ını tespit etmek için ise her bir grupta toplam 1.000 hücre sayılmış, MN'li hücrelerin varlığ $\breve{1}_{1}$ mikroskopta tespit edilerek X500 büyütmede fotoğraflandırılmıştır. MN'li hücrelerin tespitinde Fenech et al., (2003) tarafından öngörülen kriterler esas alınmıştır. Bu göre; MN'nin çapı, hücre nukleusunun 10/1'i kadar olmalı, MN yuvarlak yâda oval olmalı, MN'nin sinırları hücre nukleusundan net bir biçimde ayırt edilebilmeli yâda nukleus zarına temas olması halinde aradaki sınır açıç̧a seçilebilmelidir. Mitotik indeksi (MI) hesaplamak için hazırlanan preparatlardan her bir kök ucu için 1.000 hücre sayılmış ve mitoza giren hücrelerin yüzdesi "Eşitlik 2" kullanılarak hesaplanmıştır.

\section{Mitotik İndeks $(M I)=\frac{\text { Mitoza giren hücre sayısı }}{\text { Toplam hücre sayısl }} \times 100$}

\section{Anatomik Gözlemler}

Anatomik hasarın belirlenmesi amacıyla, uygulama periyodu sonunda paraben ile muamele edilen tohumların kök uçlarından enine kesitler alınarak, metilen mavisi ile boyanmış, entellen yardımıyla kapatılarak daimi preparat haline getirilmiş ve X500 büyütmede fotoğraflandırılmıştır.

\section{İstatistiksel Analiz}

Elde edilen verilerin istatiksel analizi "IBM SPSS Statistics 22" paket programı kullanılarak gerçekleştirilmiştir. Veriler ortalama \pm standart sapma (SD) olarak gösterilmiş, ortalamalar arasındaki istatistiksel önem "One-way ANOVA ve "Duncan" testi kullanılarak belirlenmiş ve $\mathrm{p}$ değeri $<0.05$ olduğunda istatistiksel olarak anlamlı kabul edilmiştir.

\section{BULGULAR VE TARTIȘMA}

Paraben uygulamasının fizyolojik parametreler olan çimlenme yüzdesi, kök uzunluğu ve ağırlık artışı üzerine etkileri Şekil 1 ve Çizelge 1'de gösterilmiştir. En fazla çimlenme yüzdesi, kök uzunluğu ve ağırlık artış1 kontrol grubunda, en az ise $500 \mathrm{mM}$ dozunda paraben uygulanan Grup IV'de belirlenmiştir. Kontrol grubunda $\% 100$ oranında çimlenme yüzdesi, ortalama $6.69 \mathrm{~cm}$ kök uzunluğu ve ortalama +7.46 g'llk bir ağırlık artışı tespit edilirken, Grup IV'de \% 60 oranında çimlenme yüzdesi, ortalama $0.90 \mathrm{~cm}$ kök uzunluğu ve ortalama +1.44 gram ağırlık artış1 ölçülmüştür. Kontrol grubuna göre, Paraben uygulanan gruplarda, ölçülen her üç fizyolojik parametrede belirlenen azalmanın $\mathrm{da}$ istatistiksel olarak anlamlı olduğu $(\mathrm{p}<0.05)$ gözlenmiştir.

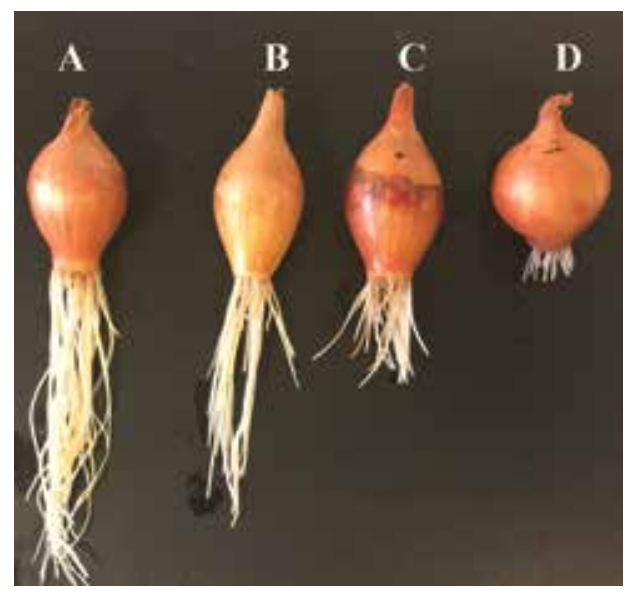

Şekil 1. Paraben' in kök uzunluğuna etkisi (a: kontrol, b: $100 \mathrm{mM}$ Paraben, c: $250 \mathrm{mM}$ Paraben, d: $500 \mathrm{mM}$ Paraben) 
Deniz KURT ve Ark.

Çizelge 1. Paraben uygulamasının kök uzunluğuna $(\mathrm{cm})$ etkisi

\begin{tabular}{|c|c|c|c|c|c|}
\hline \multirow{2}{*}{$\begin{array}{l}\text { Paraben } \\
\text { uygulama } \\
\text { dozları }\end{array}$} & \multirow{2}{*}{$\begin{array}{c}\text { Çimlenme } \\
\text { yüzdesi (\%) }\end{array}$} & \multirow{2}{*}{$\begin{array}{c}\text { Ortalama } \\
\text { kök uzunluğu } \\
(\mathrm{cm})\end{array}$} & \multicolumn{3}{|c|}{ Ăğırlık artışı (g) } \\
\hline & & & Başlangıç & Son & Ortalama \\
\hline Kontrol & 100 & $6.69 \pm 0.94^{\mathrm{a}}$ & $8.19 \pm 1.36^{\mathrm{c}}$ & $15.65 \pm 2.38^{\mathrm{a}}$ & +7.46 \\
\hline $100 \mathrm{mM}$ & 77 & $4.57 \pm 0.85^{\mathrm{b}}$ & $8.09 \pm 1.42^{\mathrm{c}}$ & $13.20 \pm 2.10^{\mathrm{b}}$ & +5.11 \\
\hline $250 \mathrm{mM}$ & 70 & $2.57 \pm 0.43^{\mathrm{c}}$ & $8.23 \pm 1.01^{\mathrm{c}}$ & $11.73 \pm 2.25^{\mathrm{b}}$ & +3.50 \\
\hline $500 \mathrm{mM}$ & 60 & $0.90 \pm 0.59^{\mathrm{d}}$ & $8.25 \pm 1.86^{\mathrm{c}}$ & $9.69 \pm 2.47^{\mathrm{c}}$ & +1.44 \\
\hline
\end{tabular}

*Veriler ortalama \pm standart sapma (SD) olarak gösterildi $(n=10)$. Çimlenme yüzdesi için $n=30$. Ortalamalar arasındaki istatistiksel önem "Duncan" testini takiben "One-way" ANOVA varyans analizi kullanılarak belirlendi. Aynı sütün içerisinde farklı harfler ile gösterilen ortalamalar istatistiksel açıdan önemlidir $(\mathrm{p}<0.05)$

Paraben uygulamasının kök ucu hücrelerinde teşvik ettiği MN ve kromozomal hasarlar ile MI sayıları Şekil 2 ve Çizelge 2'de gösterilmiştir. Kontrol grubu kök ucu hücrelerinde MN oluşumuna rastlanmazken, paraben uygulanan kök uçlarında ise uygulanan paraben dozuna bağlı olarak, MN sıklığında belirgin bir artış tespit edilmiştir. Parabenin $100 \mathrm{mM}, 250$ $\mathrm{mM}$ ve $500 \mathrm{mM}$ dozlarına maruz kalan gruplarda, sirasiyla ortalama $9.50,17.40$ ve 33.80 oranında $\mathrm{MN}$ sayılmıştır. Diğer yandan, mikroskobik incelemelerde, kontrol grubu tohumların kök ucu hücrelerinde her hangi bir kromozomal hasar gözlenmezken, Paraben uygulanan gruplarda ise sirasiyla fragment $>$ yapışkan kromozom $>$ kromozom köprüsü $>$ kromatinin eşit olmayan dağllımı >c-mitoz şeklinde kromozomal hasarlar gözlenmiştir. Bölünen hücrelerin sayısını gösteren MI değeri ise en fazla kontrol grubu tohumların kök ucu hücrelerinde, en az ise paraben'in $500 \mathrm{mM}$ dozuna maruz kalan Grup IV'deki tohumların kök ucu hücrelerinde belirlenmiştir.
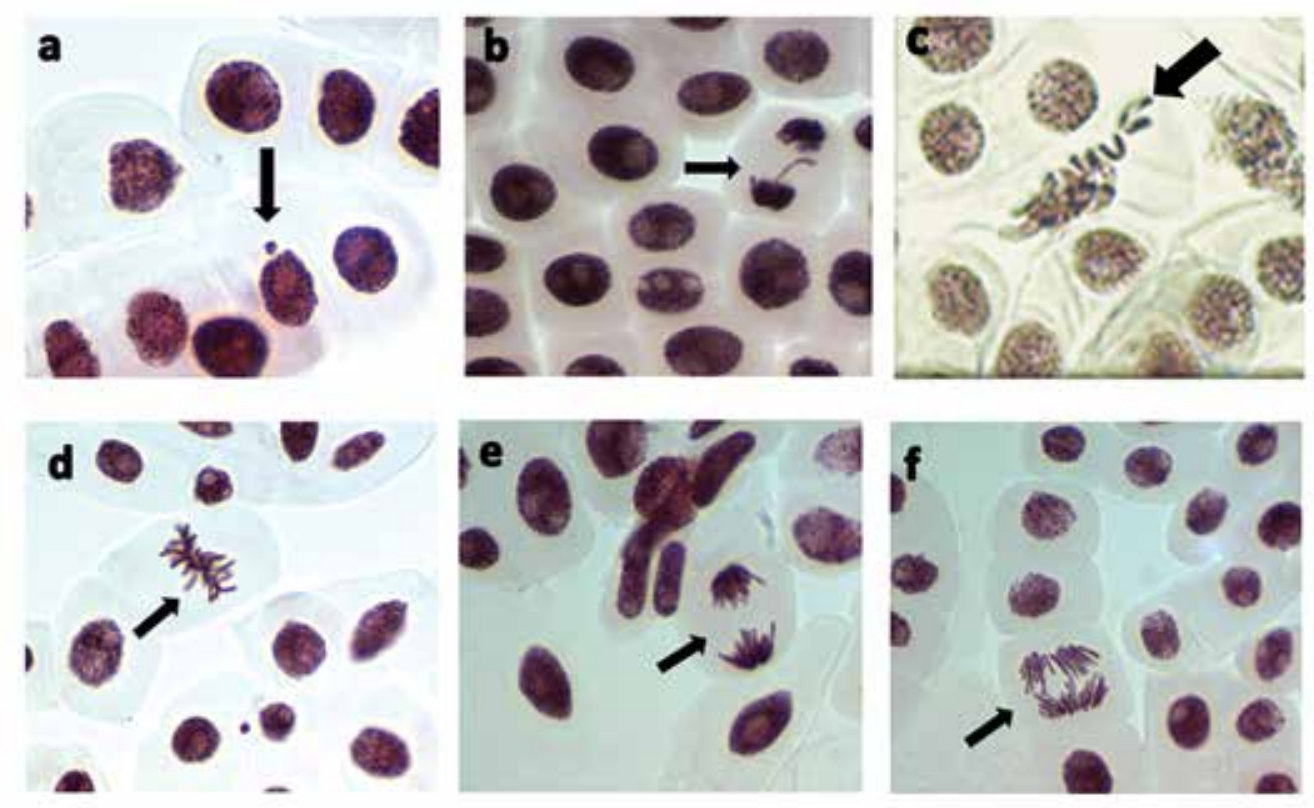

Şekil 2. Paraben tarafından teşvik edilen kromozomal hasarlar (a: MN, b: fragment, c: C-mitoz, d: yapışkan kromozom, e: kromatinin eşit olmayan dağılımı, f: kromozom köprüsü)

Paraben uygulamasının $A$. cepa L. kök ucu hücrelerinde teşvik ettiği anatomik hasarlar Şekil 3'de gösterilmiştir. Mikroskobik gözlemler sonucunda, paraben uygulanan gruplarda yassılaşmış hücre çekirdeği, nekroz, korteks hücre çeperlerinde kalınlaşma, belirgin olmayan iletim doku, hücre deformasyonu ve korteks hücrelerinde bazı maddelerin birikimi şeklinde hasarlar gözlenmiştir. 
Çizelge 2. Paraben tarafından teşvik edilen mikronukleus (MN) ve kromozomal hasarlar ve MI oranları

\begin{tabular}{lccccccc}
\hline $\begin{array}{l}\text { Paraben } \\
\text { uygulama } \\
\text { dozlar }\end{array}$ & MN & $\begin{array}{c}\text { MI } \\
(\%)\end{array}$ & FRG & YK & KK & KED & CM \\
\hline Kontrol & $0.00 \pm 0.00^{\mathrm{d}}$ & 9.18 & $0.00 \pm 0.00^{\mathrm{d}}$ & $0.00 \pm 0.00^{\mathrm{d}}$ & $0.00 \pm 0.00^{\mathrm{d}}$ & $0.00 \pm 0.00^{\mathrm{d}}$ & $0.00 \pm 0.00^{\mathrm{d}}$ \\
$100 \mathrm{mM}$ & $9.50 \pm 3.60^{\mathrm{c}}$ & 7.84 & $7.20 \pm 2.44^{\mathrm{c}}$ & $6.90 \pm 1.85^{\mathrm{c}}$ & $4.30 \pm 1.64^{\mathrm{c}}$ & $3.10 \pm 1.20^{\mathrm{c}}$ & $1.70 \pm 1.06^{\mathrm{c}}$ \\
$250 \mathrm{mM}$ & $17.40 \pm 3.13^{\mathrm{b}}$ & 6.56 & $15.50 \pm 2.84^{\mathrm{b}}$ & $12.50 \pm 3.27^{\mathrm{b}}$ & $7.30 \pm 1.64^{\mathrm{b}}$ & $6.60 \pm 2.01^{\mathrm{b}}$ & $4.10 \pm 1.20^{\mathrm{b}}$ \\
$500 \mathrm{mM}$ & $33.80 \pm 6.03^{\mathrm{a}}$ & 4.76 & $34.60 \pm 6.10^{\mathrm{a}}$ & $20.10 \pm 4.18^{\mathrm{a}}$ & $13.40 \pm 2.95^{\mathrm{a}}$ & $10.30 \pm 2.75^{\mathrm{a}}$ & $7.00 \pm 1.76^{\mathrm{a}}$ \\
\hline
\end{tabular}

* Veriler ortalama \pm standart sapma (SD) olarak gösterildi $(\mathrm{n}=10)$. MN ve MI her bir kök ucu için 1000 hücre toplamda 10000 hücre sayılarak, kromozomal hasarlar ise her bir gruptaki, her bir kök ucundan 100 hücre, toplamda ise 1000 hücre analiz edilerek hesaplandı. Ortalamalar arasındaki istatistiksel önem "Duncan" testini takiben "One-way" ANOVA varyans analizi kullanılarak araştırıldı. Aynı sütün içerisinde farklı harfler ile gösterilen ortalamalar istatistiksel açıdan önemlidir (p<0.05). (FRG: fragment, YK: yapışkan kromozom, KK: kromozom köprüsü, KED: kromatinin eşit olmayan dağılımı, CM: c-mitoz)

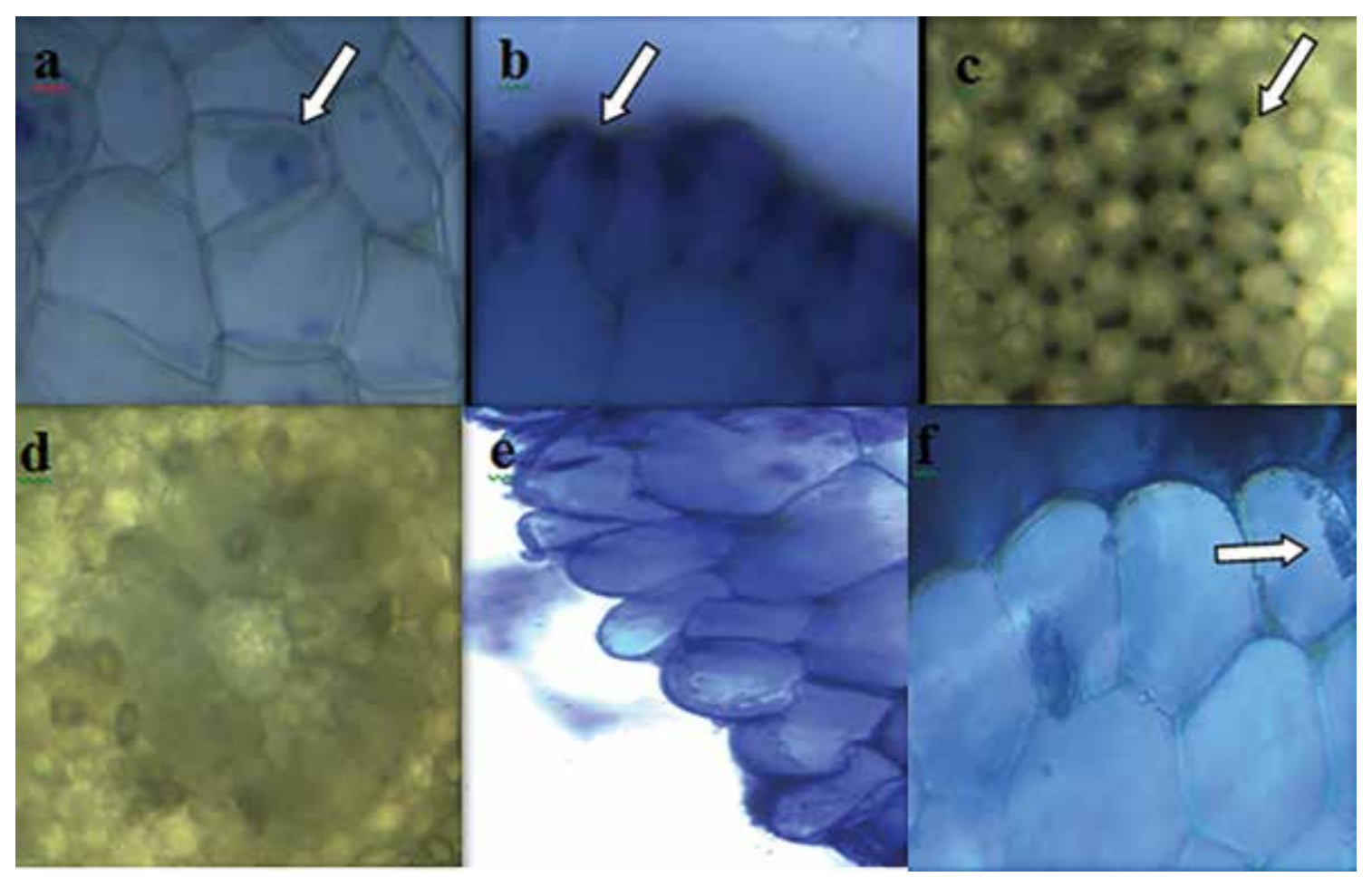

Şekil 3. Paraben uygulamasının $A$. cepa kök ucu hücrelerinde teşvik ettiği anatomik hasarlar (a: yassılaşmış hücre çekirdeği, b: nekroz, c: korteks hücre çeperlerinde kalınlaşma, d: belirgin olmayan iletim doku, e: hücre deformasyonu, f: korteks hücrelerinde bazı maddelerin birikimi)

$\mathrm{Bu}$ çalışmada, günlük yaşamımızda sıkça kullandığımız temizlik ve kozmetik ürünleri başta olmak üzere pek çok ürünün yapısında yer alan paraben'in A. сера L. test materyalinde teşvik ettiği fizyolojik, sitogenetik ve anatomik değişimler araştırılmıştır. Fizyolojik değişimler; çimlenme yüzdesi, ağırlık artış1 ve kök uzunluğu parametrelerinin ölçülmesiyle, sitogenetik değişimler MN, kromozomal anormallik ve MI sayılarının tespitiyle, anatomik değişimler ise kök ucu hücrelerinden alınan kesitlerin mikroskop altında incelenmesiyle belirlenmiştir.
Araştırma sonucunda, paraben'in uygulama dozu ile ters orantıli olarak, fizyolojik parametrelerden çimlenme yüzdesi, ağırlık artışı ve kök uzunluğunu azalttığı tespit edilmiştir. Literatürde paraben'in bitkisel kaynaklı test materyallerinde fizyolojik değişimlere sebep olduğunu gösteren çok fazla çalışma olmamasına rağmen, diğer kimyasal ajanlarla gerçekleştirilen pek çok çalışma bulunmaktadır. Örneğin Herrero et al., (2012) tarafından gerçekleştirilen bir çalışmada, Di (2-etilheksil) Ftalat, Triklosan ve Propilparaben'in $A$. cepa'da teşvik ettiği fizyolojik değişimler araştırılmış, 
sonuçta Di (2-Etilheksil) Ftalat'ın kök gelişimini inhibe edici belirgin bir etkisinin olmadığı, fakat diğer iki kimyasalın ise $A$. серa $\mathrm{L}$. kök gelişimini doza bağlı olarak inhibe ettiği rapor edilmiştir. Çavuşoğlu et al., (2012) tarafindan gerçekleştirilen bir başka çalışmada ise 72 saat süresince Tiametoksam'ın 100, 250 ve $500 \mathrm{mg} \mathrm{kg}^{-1}$ dozlarına maruz kalan $A$. cepa L. tohumlarının çimlenme yüzdesi, kök uzunluğu ve ağırlık artışındaki değişimler araştırılmış, sonuçta Tiametoksam'ın araştırılan her üç fizyolojik parametrede de, uygulama dozuna bağlı olarak azalmaya sebep olduğu belirlenmiştir. Gupta et al., (2016) tarafından gerçekleştirilen bir diğer çalışmada ise Çinko (Zn) $(250,500,750,1000$ ve 1250 mg kg-1) ve Kurşun (Pb)'un (200, 400, 600, 800, 1000 $\mathrm{mg} \mathrm{kg}{ }^{-1}$ ) farklı konsantrasyonlarının soya fasulyesinin [Glycine max (L.) MERR] büyüme parametreleri üzerine etkileri araştırılmış, sonuçta $\mathrm{Pb}$ 'nin uygulanan tüm konsantrasyonlarda çimlenme yüzdesi ve kök uzunluğunu kontrol grubuna göre azalttığ $1, \mathrm{Zn}$ 'nin ise düşük konsantrasyonlarda çimlenme yüzdesi ve kök uzunluğundaki artışı teşvik ettiği, yüksek dozlarda (750, 1000 ve $1250 \mathrm{mg} \mathrm{kg}^{-1}$ ) ise inhibe ettiği tespit edilmiştir.

Paraben uygulamasının bir diğer olumsuz etkisi ise sitogenetik parametreler üzerine olmuştur. Uygulanan Paraben dozuna bağlı olarak MN ve kromozomal hasar sayıları artmış, MI değeri ise önemli oranda azalmıştır. Literatürde bitkisel kaynaklı test materyallerinde paraben tarafindan teşvik edilen sitogenetik değişimleri araştıran kapsamlı bir çalışma olmasa da, diğer kimyasalların sebep olduğu sitogenetik değişimleri araştıran pek çok çalışma bulunmaktadır. Örneğin Nefic et al., (2013) tarafından gerçekleştirilen bir çalışmada, 24 saat süresince Alprazolam'in 100, 150, 200, 250 ve $500 \mu \mathrm{g} \mathrm{mL}^{-1}$ konsantrasyonlarına maruz kalan $A$. сера L. kök ucu hücrelerinde nüklear ve morfolojik değişiklikler araştırılmış, sonuçta Alprazolam'ın tüm konsantrasyonlarda nükleer tomurcuklanma, parçalanmış hücre çekirdeği, apoptotik cisimler, çekirdeksiz, binüklear ve mikronukleuslu hücre oluşumu şeklinde morfolojik değişiklikler ile anafaz köprüsü, kırıklar, gecikme ve yapışkanlık, anormal spiralizasyon, çoklu kutuplaşma ve poliploidi şeklinde nüklear değişikliklere sebep olduğu, ayrıca MI azalttığ 1 rapor edilmiştir. De Compos VentureCamargo et al., (2016) tarafından gerçekleştirilen bir başka çalışmada ise Atrazin'in 0.062, 0.031, 0.015 ve 0.125 ppm konsantrasyonlarının $A$. cepa L. kök ucu hücrelerinde sebep olduğu genotoksisite araştırılmış, sonuçta Atrazin'in test edilen tüm konsantrasyonlarda genotoksik olduğu, kök ucu hücrelerinde MI azalttığı, ayrıca multipolar anafaz, köprü, kromozom kırığı, gecikme, c-metafaz, genetik materyalin kaybı ve mikronukleus şeklinde kromozomal anormalliklere sebep olduğu belirlenmiştir.

Paraben uygulaması $A$. серa L. kök uçlarında anatomik değişimlere de sebep olmuştur. 72 saat süresince paraben'in üç farklı dozuyla muamele edilen kök uçlarından alınan kesitlerin mikroskop altında incelenmesi sonucunda yassılaşmış hücre çekirdeği, nekroz, korteks hücre çeperlerinde kalınlaşma, belirgin olmayan iletim doku, hücre deformasyonu ve korteks hücrelerinde bazı maddelerin birikimi şeklinde anatomik hasarlar gözlenmiştir. Literatürde kök ucu hücrelerinde doğrudan paraben ile ilgili olmasa da, diğer kimyasal ajanlar tarafından sebep olunan anatomik değişimleri inceleyen bazı çalışmalar bulunmaktadır. Örneğin Demirtaş et al., (2015) tarafindan gerçekleştirilen bir çalışmada, Dinikanazol'ün 25,50 ve 100 ppm dozlarının A. серa $\mathrm{L}$. kök ucu hücrelerinde teşvik ettiği anatomik değişimler araştırılmış, sonuçta Dinikanazol'ün kök ucu hücrelerinde hücre deformasyonu, belirgin olmayan iletim doku, yassılaşmış hücre çekirdeği ve nekroz şeklinde anatomik değişimlere neden olduğu rapor edilmiştir. Çavuşoğlu et al., (2012) tarafindan gerçekleştirilen bir diğer çalışmada ise, Tiametoksam'ın üç farklı dozuna $\left(100,250\right.$ ve $\left.500 \mathrm{mg} \mathrm{kg}^{-1}\right)$ maruz kalan A. серa kök ucu hücrelerindeki anatomik değişimler araştırılmış, mikroskobik gözlemler sonucunda kök uçlarında nekrotik hücre ölümü, belirgin olmayan iletim doku ve epidermis tabakası ile hücre deformasyonu ve hücre çekirdeğinin olağan görünümü şeklinde anatomik hasarlar gözlenmiştir. Acar et al., (2015) tarafindan gerçekleştirilen benzer tarzdaki bir başka çalışmada ise, Paraquat' 1 10, 50 ve 100 ppm dozlarının A. cepa L. kök ucu hücrelerinde meydana getirdiği anatomik değişimler araştırılmış, sonuçta kök ucu hücrelerinde hücre çekirdeğinin olağan dışı şekli, nekroz, belirgin olmayan iletim doku, iletim dokuda bazı maddelerin birikimi ve hücre deformasyonu şeklinde hasarlar tespit edilmiştir.

\section{SONUÇ}

Günlük yaşamımızda sıkça kullandığımız pek çok ürünün yapısında yer alan paraben'in belirli bir doz seviyesinde toksik etki gösterdiği, $A$. серa $\mathrm{L}$. test materyalinin ise söz konusu toksisitenin belirlenmesinde kullanışlı bir biyolojik indikatör olduğu gösterilmiştir.

\section{TEŞEKKÜR}

$\mathrm{Bu}$ çalışmamızı FEN-BAP-C-250414-08 nolu proje ile destekleyen, Giresun Üniversitesi Bilimsel Araştırma Projeler (BAP) Birimi Koordinatörlüğü'ne teşekkür ederiz. 


\section{KAYNAKLAR}

Acar A, Çavuşoğlu K, Türkmen Z, Çavuşoğlu K, Yalçın E, 2015. The Investigation of Genotoxic, Physiological and Anatomical Effects of Paraquat Herbicide on Allium cepa L. Cytologia 80 (3): 343-351.

Andersen FA, 2008. Final Amended Report on the Safety Assessment of Methylparaben, Ethylparaben, Propylparaben, Isopropylparaben, Butylparaben, Isobutylparaben, and Benzylparaben As Used In Cosmetic Products. International Journal of Toxicology, 18 (2): 5-7.

Atik M, Karagüzel O, Ersoy S, 2007. Sıcaklı̆̆ın Dalbergia sissoo Tohumlarının Çimlenme Özelliklerine Etkisi. Akdeniz Üniversitesi Ziraat Fakültesi Dergisi, 20 (2): 203-210.

Çavuşoğlu K, Yalçın E, Türkmen Z, Yapar K, Sağır S, 2012. Physiological, Anatomical, Biochemical and Cytogenetic Effects of Thiamethoxam Treatment on Allium cepa (Amaryllidaceae) L. Environmental Toxicology, 27 (11): 635-643.

De Campos Ventura-Camargo B, Marin-Morales M.A, Desk S, 2016. Micronuclei and Chromosome Aberrations Derived from the Action of Atrazine Herbicide In Allium cepa Meristematic Cells. SDRP Journal of Earth Sciences \& Environmental Studies, 1 (1): 1-7.

Demirtaş G, Çavuşoğlu K, Yalçın E, 2015. Anatomic, Physiologic and Cytogenetic Changes in Allium cepa L. Induced by Diniconazole. Cytologia, 80 (1): 51-57.

Fenech M, Chang WP, Kirsch-Volders M, Holland N, Bonassi S, Zeiger E, 2003. HUMN Project: Detailed Description of The Scoring Criteria for the Cytokinesis-Block Micronucleus Assay Using Isolated Human Lymphocyte Cultures. Mutation Research, 534 (1): 65-75.

Gupta S, Meena MKR, Datta S, 2016. Effect of Selected Heavy Metals (Lead and Zinc) on Seedling Growth of Soybean Glycine $\max (\mathrm{L}$.) MERR. International Journal of Pharmacy and Pharmaceutical Sciences, 8 (8): 302-330.

Herrero O, Martín JP, Freire PF, López LC, Peropadre A, Hazen MJ, 2012. Toxicological Evaluation of Three Contaminants of Emerging Concern by Use of the Allium cepa Test. Mutation Research/Genetic Toxicology and Environmental Mutagenesis, 743 (1): 20-24.
Johnsson S, Lind ML, Boman A, Liden C, 2011. Preservatives and Fragrances In Selected Consumer-available Cosmetics and Detergents. Contact Dermatitis, 64 (5): 265-272.

Kang KS, Che JH, Ryu DY, Kim TW, Li GX, Lee YS, 2002. Decreased Sperm Number and Motile Activity on the F1 Offspring Maternally Exposed to Butyl P-Hydroxybenzoic Acid (Butyl Paraben). Journal of Veterinary Medical Science, 64 (3): 227-235.

Kirchhof MG, de Gannes GC, 2013. The Health Controversies of Parabens. Skin Therapy Letter, 18 (2): 5-7.

Nefic H, Musanovic J, Metovic A, Kurteshi K, 2013. Chromosomal and Nuclear Alterations In Root Tip Cells of Allium cepa L. Induced by Alprazolam. Medical Archives, 67 (6): 388.

Slobodkin LB, 1967. Toward A Predictive Theory of Evolution. In Lewontin, RC. (Ed.) Population Biology and Evolution, 187-205 p. Proceedings International Symposium, Syracuse University and NYS Science and Technology Foundation. Syracuse University Press, Syracuse, New York.

Song BL, Li HY, Peng DR, 1989. In Vitro Spermicidal Activity of Parabens Against Human Spermatozoa. Contraception, 39 (3): 331-3355.

Staykova TA, Ivanova EN, Velcheva IG, 2005. Cytogenetic Effect of Heavy Metal and Cyanide In Contamined Waters from the Region of Southwest Bulgaria. Journal of Cell and Molecular Biology, 4: 41-46.

Wei QX, 2004. Mutagenic Effects of Chromium Trioxide on Root Tip Cells of Vicia faba. Journal of Zhejiang University Science, 5: 1570-1576.

Witorsch RJ, Thomas JA, 2010. Personal Care Products and Endocrine Disruption: A Critical Review of The Literature. Critical Reviews in Toxicology, 40 (3): 1-30.

Yücel, 2006. Canlılar ve Çevre. http://docplayer.biz.tr/4935493Canlilar-ve-cevre-unite-amaclar-icindekiler-yazar-doc-drersin-yucel.html. (Erişim tarihi: 26 Ekim, 2017). 